\title{
Modern Trends in the Development of the Regional Economic Management System in the Context of Digital Globalization
}

\author{
Olga Prikhodchenko ${ }^{1, *}$, Vladimir Panskov ${ }^{2}$, Lubov Afanasyeva ${ }^{1}$ \\ ${ }^{1}$ Southwest State University, Faculty of Economics and Management, 50 Let Oktyabrya str. 94, \\ 305040 Kursk, Russian Federation \\ ${ }^{2}$ Finance University under the Government of the Russian Federation, 49, Leningradsky avenue, \\ 125993 Moscow, Russian Federation
}

\begin{abstract}
.
Research background: In modern conditions of the digital transformation of the economy, digital data are key factors in the development of the socio-economic sphere. Inevitably, the digitalization process is accompanied by the development and transformation of human resources, the formation of a knowledge economy, which leads to serious changes in social relations, the economic sphere and the labor market both at the state level and at the level of regional systems.

The scientific interest in the research topic is due to the fact that effective strategic management of the region, the possibilities of its socio-economic development are largely determined by the development of the digital economy at the regional level.

Purpose of the article: development of a model of digital transformation at the regional level, which will improve the quality of strategic management based on the results.

Methods: a method of theoretical analysis of the sources of the studied problem, an illustrative-graphic method, general scientific methods of cognition (synthesis, generalization).

Findings \& Value added: Currently, digital transformation penetrates into all areas, including socio-economic, financial, public administration. Therefore, the mechanism of strategic management of the region should be based on digitalization technologies.

In this article, the author reviews foreign and domestic studies on the introduction of modern digital technologies in public administration.

The article discusses the existing digital platforms designed to improve the efficiency of the processes of program-targeted and design-targeted management of budgetary resources.
\end{abstract}

\footnotetext{
${ }^{*}$ Corresponding author: olgaprikhodchenko@yandex.ru
} 
Effective strategic management of the development of the region in modern conditions is possible taking into account the processes of digital transformation. Based on the study, the author constructed a model of digital transformation at the regional level, characterized its main elements.

Keywords: strategic management; digitalization; digital transformation; public administration; regional management

JEL Classification: $021 ; E 66 ; P 43$

\section{Introduction}

Currently, a new information society is being formed, which is called the "digital economy". The introduction of the "digital economy" is a lever for the development of the economic structure and the environment as a whole.

In the medium term, one of the strategic state tasks is the digitalization of the Russian economy. For Russia, the development of digitalization of the economy and society is relevant and significant, which determined the scientific interest in the research topic.

Effective strategic management of the socio-economic development of the region, based on program-target and design-target approaches, in modern conditions is possible only taking into account the processes of digital transformation.

\section{Literature review}

The works [1-4] explore various theoretical and practical aspects of the implementation and development of financial, tax, information and management spheres in the context of digital transformation.

In recent years, in domestic science, various issues of strategic management of the region have been devoted to scientific works of researchers [5-11].

One of the key factors ensuring the effective functioning of the system of project-target management and program-target planning in the budgetary sphere is the improvement of the information system for creating, processing data and subsequent monitoring and control, based on modern digital transformation tools.

A number of theoretical and practical studies are devoted to the management of budget expenditures in the context of digitalization [12-14].

The issues of program-targeted management at the regional level are touched upon in the studies of modern domestic economists $[15,16]$.

The problems of the development of digital technologies in the public administration system are in the focus of attention of the executive authorities, leading international and Russian scientific and expert centers.

In the context of the accelerated development of the Russian economy and its integration into the world economy, strategic management at the state and regional levels is of particular importance.

In modern conditions, one of the drivers of effective public administration of the region, its socio-economic development is the formation of the digital economy.

\section{Results}


Of particular importance in modern conditions are issues related to the creation of an effective and flexible system for managing economic processes capable of adapting to the factors of the external and internal environment based on the tools of the digital economy.

Thanks to digitalization technologies, the processes taking place in all areas - economy, finance, social sphere, public administration are significantly accelerated. In turn, all this leads to qualitative changes both in the economy and in society as a whole.

At the present stage, the digital economy implies the presence of large-scale digital data, ways of storing, processing, analyzing and protecting them, on the basis of which tactical and strategic decisions are made. Digitalization processes contribute to the development of various spheres of social activity and are already being actively implemented in the field of state and regional administration, socio-economic development, business, and the financial sphere.

The development of digital technologies has a significant impact on the economy, causing transformations at various levels: state, regional, local.

As noted in the Digital Single Market Strategy for Europe, less than ten years from now, major economic activities will depend on digital ecosystems, the integration of digital infrastructure, hardware and software, applications and data [17].

Strategic state (regional) management in modern conditions should be based on the concept of the digital economy, which is confirmed by the provisions of the Strategy for the Development of the Information Society in the Russian Federation for 2017 - 2030, approved in 2017 by the Decree of the President of the Russian Federation [18]. In this strategic document, among the national interests in the field of the digital economy, an increase in the efficiency of public administration is presented through the use of new technologies in the state authorities of the Russian Federation that ensure an improvement in the quality of public administration.

In order to implement this strategy, the Government of the Russian Federation approved the national program "Digital Economy of the Russian Federation", which includes six federal projects aimed at the development of digital technologies and their use in various fields.

In modern conditions, the imperatives of the socio-economic development of the region pose a large-scale task - to move from the development of the communications industry and the implementation of individual IT projects to a comprehensive digital transformation and building a digital economy.

The goal of the development of the digital economy in the region is to create favorable conditions for the development of institutions of the digital economy and integration into the global information society through a qualitative change in the structure and management system of economic assets.

Digital transformation at the regional level will allow solving a number of tasks:

- growth of investment attractiveness of the regional digital economy, which will increase the volume of investments in regional projects;

- increasing the growth rate of gross regional product and labor productivity through the introduction of digital transformation processes in various sectors of the economy and the management system;

- reduction of labor intensity and, as a consequence, reduction of expenditures in the public administration sector;

- shortening the cycle of making management decisions and increasing their efficiency;

- increasing the efficiency of electronic services, the level of digital literacy of the population and digital competencies of business. 
The development of digital transformation processes is associated with the creation of new digital products, services and services, information technologies, digital platforms. Currently, the priority area for the development of the digital economy at the regional level is the use of digital platforms.

Measures for the formation of digital platforms are actively involved in various federal projects and plans. Thus, a digital platform has been formed for interaction in the field of strategic management in order to coordinate the actions of participants in strategic planning at all levels of government within the framework of the federal project "Digital Public Administration".

Initially, the use of digital platforms was the prerogative of large and high-tech companies; at the present stage, digital platforms are available to a wide range of users.

The need for the development of digital platforms is associated, first of all, with the complexity of managing the processes of the digital economy, which require an effective, understandable and convenient organizational form. At the same time, the activities of the state should be aimed at uniting participants in information activities and creating the necessary conditions for the development of information and digital platforms.

In the financial and budgetary sphere of the region, the digital economy can be described as a system of financial and budgetary relations based on the development and implementation of digital technologies and digital platforms that will allow the development and implementation of financial and budget forecasts, plans and programs, as well as monitoring and organizing the state financial control in the constituent entities of the Russian Federation.

Since the 2010s. in the field of financial management, new platforms and tools for organizing information flows are gradually being introduced.

Such a digital platform is the State Integrated Information System (GI IS) for public finance management "Electronic Budget", which is designed to improve the quality of financial management of state bodies through the introduction of information and communication technologies and the creation of a single information space in the environment of state, municipal and public finance management.

The use of the GI IS "Electronic Budget" will allow public authorities to achieve three priority goals.

The first goal is to increase the level of transparency of the decision-making procedure and the results of activities in the public sector. For various users within the framework of this system, such documents as reporting data, projects, forecasts are available.

The International Budget Partnership is conducting a study of the openness of the budget, within the framework of which the integral indicator of transparency of information on public finances (Open Budget Index) is calculated (Fig. 1).

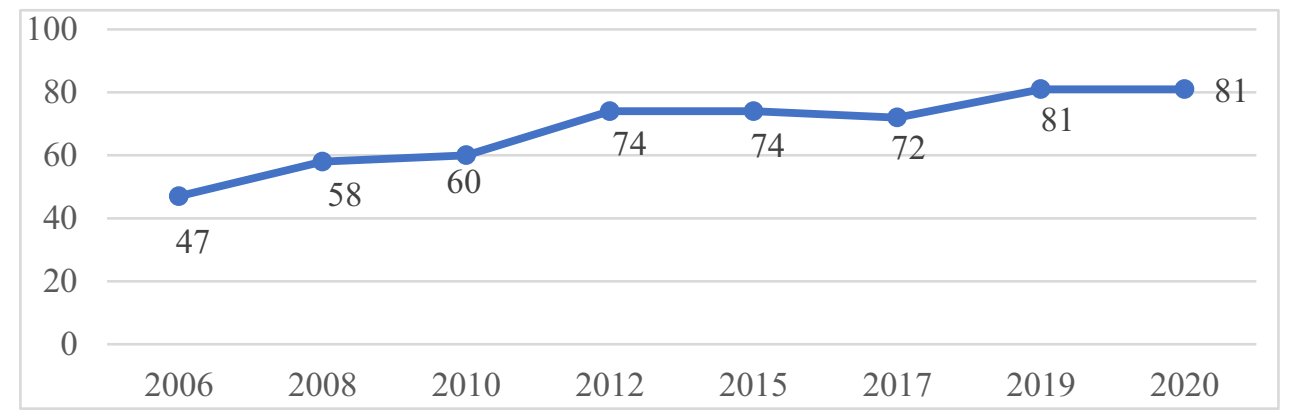

Fig. 1. Dynamics of the Russian Open Budget Index; Source: [19] 
The value of the index in 2017 is interpreted as a sufficient level of budgetary openness, namely, there is significant information about the budget.

The values of this index are included in the list of target indicators of the state program "Public Financial Management and Regulation of Financial Markets". In 2019-2020. the planned index value is 81 , which means there is a lot of information.

The digital platform "Electronic Budget" will increase this indicator and enter Russia into the group of countries with the highest transparency of public finance.

One of the priority tasks in the digital economy is the digitalization of regional governance to reduce transaction costs and improve the efficiency of decisions. In the field of digitalization of regional administration, the following areas can be distinguished:

1) work to increase the openness of management (development of electronic services, publication of data on the work of government bodies; transparency of the budget for citizens);

2) improving the interface of interaction with citizens (digitization of public services; MFC);

3) creation of situational centers to respond to changes in the political and economic environment and increase the efficiency of decisions.

Figure 2 shows the positive results that the digital transformation of regional governance will lead to.

reduction of costs for government bodies to perform their functions due to their optimization

improving the efficiency of government agencies in the provision of public services and the implementation of control and supervisory activities through standardization and modernization of administrative

reduction of costs for the creation and administration of information resources and systems due to the reuse of information technologies and services by various government agencies

increasing the efficiency of program budget expenditures in the region

increasing the level of confidence of citizens and businesses in government bodies and officials

Fig. 2. The positive effect of the digital transformation of regional governance; Source: [20]

The main goal of introducing digital technologies into the sphere of state (regional) management is to improve its quality, including the quality of public services and the quality of management of the implementation of national projects (programs) to ensure stable socio-economic development of the region.

The review and synthesis of modern scientific publications, analytical materials of domestic and foreign researchers and experts allows us to highlight the key elements of the digital transformation model at the regional level.

Figure 3 shows a model of digital transformation of regional governance. 


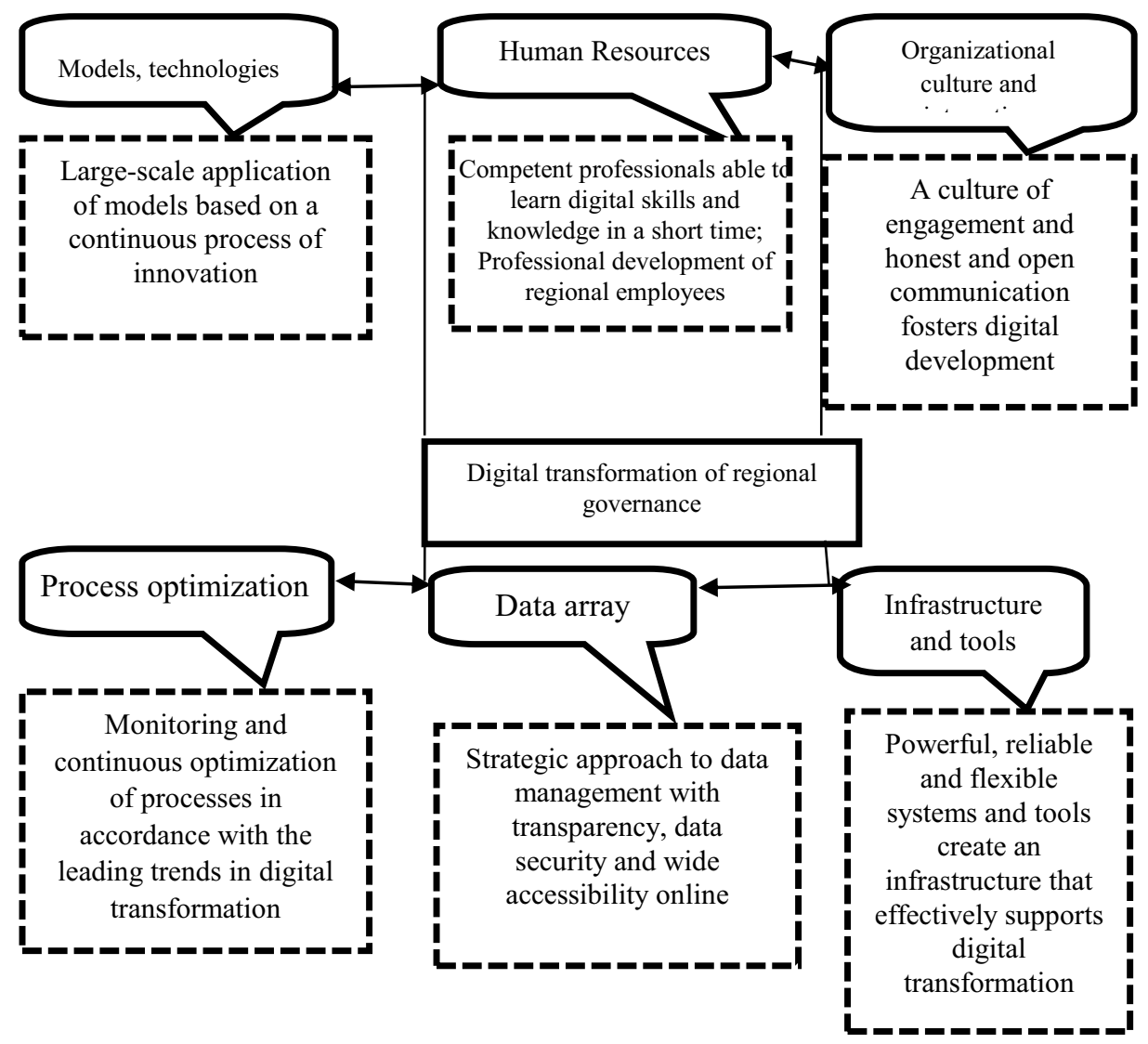

Fig. 3. Model of digital transformation of regional government.

The socio-economic policy of federal and regional authorities should be aimed at accelerating the formation of the digital economy in the regions, which requires the creation of an appropriate infrastructure, training in IT technologies, the development of the market for digital technologies and platforms, and the comprehensive use of information and communication technologies in the economic sphere., in the field of state and municipal administration.

With the development of the digital economy, distributed ledger technologies have spread.

A distributed ledger is essentially a database of assets that can be shared across a network of multiple sites, geographic regions, or institutions. Assets can be financial, legal, physical, or electronic. The security and accuracy of assets stored in a distributed ledger is secured cryptographically through the use of "keys" and signatures for control by the participants.

An important advantage of distributed ledger technology is resilience to unauthorized changes or malicious tampering.

Blockchain technology is currently attracting the most attention from researchers.

Blockchain is a multifunctional and multi-level information technology designed for reliable accounting of various assets. 
Cryptocurrencies are one of the possibilities of blockchain technology, but far from the only one. Researchers are increasingly interested in finding options and methods for using blockchain as an independent technology.

Blockchain can be used in those areas where a reliable way of processing and storing massive amounts of information is required.

According to Daryl Plummer, director of research at Gartner, there is a digital revolution currently taking place, which will gain momentum in the near future. Despite the imperfection of distributed ledger technologies, a Gartner analyst believes that blockchain will penetrate various industries within the next 2-3 years.

Gartner predicts that blockchain can be used in any industry that requires transaction verification.

In the past few years, more and more attention of Russian and foreign researchers and analysts has been attracted by the possibilities of using blockchain technology in various fields, including in the field of public administration.

So, at the beginning of 2017, at a meeting with Deputy Prime Ministers, Prime Minister Dmitry Medvedev, an order was given to the Ministry of Economic Development and the Ministry of Telecom and Mass Communications to analyze the possibility of using blockchain technology in the field of public administration and economic management in Russia.

In 2016, a report was prepared on a study conducted by the UK Government Science Office (Ledger Technology: beyondblockchain) [21]. This report states that one of the priority tasks of the state is to identify opportunities for using distributed ledger technology in public administration and in the provision of public services.

In May 2018, a member of the US Federal Reserve Board Lael Brainard prepared materials (Cryptocurrencies, DigitalCurrencies, and Distributed Ledger Technologies: What Are We Learning?) [22], which notes that distributed ledger technology (blockchain) is a mechanism for maintaining and transfer of records, which in the past few years has already gone beyond the cryptocurrency.

Effective strategic management of the development of a region in a digital economy is possible only if there are developed platforms, institutional and infrastructural environments and technologies.

In our opinion, blockchain is a promising technology that can be used in the field of strategic management of the development of the region.

Government participation in the development and implementation of blockchain technology will ultimately help reduce the complexity and cost of government.

Among the main threats to the development of the regional digital economy in general and in the financial and budgetary sector in particular, a significant place is occupied by the lack of qualified personnel, which is accompanied by a "brain drain" outside the region and the country as a whole.

The full development of the information technology industry will be facilitated by measures aimed at supporting individual enterprises, research centers, educational institutions, etc. The emergence of large research centers will allow the region to become not only a leader in the scientific and technical process, but also ensure the implementation of state programs in the field of information technology and an innovative environment, to build up human capital to work in these centers, will provide an inflow of investments both in the ICT sector itself and in related sectors of the economy.

\section{Discussion and Conclusion}


The modern public administration system is shifting to digital public administration, the creation of a national data management system, digital profiles and platforms.

Integration of digital transformation processes into the strategic system at the regional level will help to increase the efficiency of state (regional) management by increasing the speed of information exchange, building the potential for constant monitoring of socioeconomic development and making timely operational decisions, using tools for information technology support of the work process will reduce the level of dependence on the human factor.

Aknowledgements. This research was conducted with the support of the Ministry of Science and Education of Russia within the framework of the project under Agreement No. 0851-2020-0034.

\section{References}

1. Smotritskaya, I. I., \& Chernykh, S. I. (2018). Modern Trends in the Digital Transformation of Public Administration. The Bulletin of the Institute of Economics of the Russian Academy of Sciences, (5), 22-36..

2. Tkacheva, T. Y., Sevryukova, L. V., \& Afanaseva, L. V. (2016). Organizational and functional features of fiscal mechanisms: theoretical aspects and current trends. Journal of the Social Sciences, 11(15), 3692-3696.

3. TKACHEVA, T. Y., AFANASJEVA, L. V., GONCHARENKO, L. I., SEVRUKOVA, L. V., \& PANSKOV, V. G. (2019). Formation of Modern Fiscal Mechanisms: Integrated Approach. In Education Excellence and Innovation Management through Vision 2020 (pp. 6955-6959).

4. Razumovskaya E.A., Dukhani A.B.D. (2019). The Role of Digital Technologies in Optimizing the Budget Process: World and Russian Practice. Business. Education. Right, 4(49), 129-134.

5. Vertakova Yu.V. (2017). Development of a system of indicative and strategic planning in the implementation of state economic policy at all levels of government. Bulletin of the South-West State University. Series: Economics. Sociology. Management, T. 7.No,. 4(25), 30-56.

6. Trusova, N., \& Plotnikov, V. (2015). State economic policy and its territorial peculiarities. Procedia Economics and Finance, 27, 170-176.

7. Trusova, N. (2019). Government socio-economic policy under the digital economy in the foreign countries and Russia. Економічний часопис-XXI, 180(11-12), 88-96.

8. Sevriukova L. V., Trusova N. C. (2014), 'State policy to promote investment activity in regions. Economic Annals-XXI, 9-10, 106-107.

9. Rykunova, V., \& Goncharenko, L. (2017). Enhancement of the incentive function of economic mechanism for rational natural resources management. International Multidisciplinary Scientific GeoConference: SGEM, 17, 285-291.

10. Kirilchuk, I., Rykunova, V., \& Panskov, V. (2018). FEATURES OF CALCULATION AND ANALYSIS OF EKOLOGY-EKONOMIC INDEX OF THE REGION ON THE EXAMPLE OF KURSK REGION. International Multidisciplinary Scientific GeoConference: SGEM, 18(5.3), 375-382.

11. Kirilchuk I., Rykunova V., Panskov V. (2018) Iindicators of sustainable development as indicators of ecological-economic safety: Proceedings of the 18th International Multidisciplinary Scientific GeoConferences SGEM 2018, 491-498. 
12. Gupta, S., Keane, M., Shah, A., \& Verdier, G. (2018). The budgetary sphere is becoming digital. Finance \& Development: 12-15.

13. Molchanova, N.P. (2017). Development of public finance in the context of the formation of the digital economy. Scientific research of the Faculty of Economics. Electronic journal, 3(25), 7-16.

14. Plotnikov, V., Klimenko, P., Trusova, N., \& Prikhodchenko, O. (2015). Program budgeting as a mechanism to achieve social and economic development of the region. In SGEM International Multidisciplinary Scientific Conference on Social sciences and Arts (No. 2-2, р. 851). Общество с ограниченной ответственностью СТЕФ92 Технолоджи.

15. Kryzhanovskaya, O. A., Novikova, I. A., Sokolova, Yu. I. (2018). Specificity of regional project management. Bulletin of the South-West State University. Series: Economics. Sociology. Management, (29), 111-120.

16. Prikhodchenko, O., Afanasyeva, L., Devyatilova, A., \& Tciklauri, V. (2018). Current trends of results-based management in public sector. In Innovation Management and Education Excellence through Vision 2020 (pp. 4607-4614).

17. European Commission, Secretariat-General. Communication from the Commission to the European Parliament, the Council, the European economic and social committee and the Committee of the Regions. A Digital Single Market Strategy for Europe. Brussels, 05/06/2015. https: //ec.europa. eu / digital-single-market / en / news / digitalsingle-marketstrategy-europe-com2015-192-final.

18. On the strategy of development of the information society in the Russian Federation for 2017 - 2030: Decree of the President of the Russian Federation dated 09.05.2017 No. 203.

19. Official website of the International Budget Partnership Retrieved from: https://www.internationalbudget.org/open-budget-survey/.

20. State as a platform: People and technologies / ed. Shklyaruk M.S., - M: RANEPA, 2019 - p. 111. Retrieved from: https://files.data-economy.ru/Docs/GovPlatform2019. pdf.

21. Ledger Technology: beyond block chain. A report by the UK Government Chief Scientific Adviser / Government Office for Science, 2016. Retrieved from: https://www.gov.uk/government/ uploads / system / uploads / attachment_data / file / 492972 / gs-16-1-distributed-ledger-technology.pdf.

22. Lael Brainard "Cryptocurrencies, Digital Currencies, and Distributed Ledger Technologies: What Are We Learning?". Retrieved from: https://www.federalrese rve.gov/newsevents/speech/brainar. 